\section{Media and interpersonal persuasions in the polio eradication campaign in northern Nigeria}

\author{
Yakubu Ozohu-Suleiman \\ Department of Media Studies \\ Faculty of Arts and Social Sciences \\ University of Malaya, Kuala Lumpur, \\ Malaysia
}

\section{Abstract}

This study is premised on the increasing global concerns over the widespread resistance to polio eradication campaign in northern Nigeria. It aims to determine the level of campaign acceptance and compare the influences of mass media and interpersonal communication sources in Zaria local government area, being one of the high-risk (WPV-endemic) areas in northern Nigeria, where campaign resistance is known to be high. By way of quantitative survey, the study utilized $10 \%$ sample of the populations of eight out of the thirteen Wards in Zaria local government area, with a response rate of $78.6 \%$. Findings reveal close ranks between campaign acceptance and resistance in the local government area, thus further confirming the difficulties still faced in polio eradication campaign in the region. This study also indicates higher performance of Interpersonal than Mass Media sources in influencing campaign acceptance and resistance in the local communities. Contact with friends and relations was rated the most influential interpersonal sources in the acceptance and resistance decision of individuals, while newspapers and magazines were rated most influential media sources that influenced campaign resistance in the local communities. The study concludes that a polio eradication campaign, backed with competent and sufficient communication expertise that utilizes knowledge-based indigenous interpersonal communication strategies will likely result in greater community acceptance in northern Nigeria.

\section{Introduction}

Polio Eradication Programme in Nigeria has remained a topical issue of growing concerns. This is due to prolonged resistance to the internationally sponsored campaign in the northern part of the country, where resistance to the polio immunization campaign is high. ${ }^{1}$ Media reports generally attribute the resistance to Muslims in the region, while studies confirms that the resistance was partly caused by fears that the polio vaccine is contaminated with anti-fertility hormone and HIV virus ${ }^{2,3}$ and aimed at depopulating Muslims around the world. There are equally those who are apprehensive of the risks of having their children vaccinated, for reasons of lack of trust in the government; ${ }^{4}$ discontentment with the topdown vertical nature of the health intervention in which the beneficiaries have no say; ${ }^{2}$ and memories of the drug scandal of 1996 in which an untested antibiotic, Trovan (Trovafloxacin Mesylate) developed by Pfizer Inc., that was given free of charge in Kano state during the 1996 cerebrospinal meningitis (CSM) epidemic, killed 11 children and left 200 other children disabled. ${ }^{5,6}$

These apprehensions, according to the BBC have been reinforced by a suggestion that the administration of polio vaccine in East Africa in the late 1950s correlates with early cases of HIV infection in Africa: It had been suggested that HIV was initially transmitted to humans in the late 1950s through the use of an oral polio vaccine. The polio vaccine was given to at least one million people in the former Belgian Congo and what are now Rwanda and Burundi. The site of the 28-vaccination projects correlate closely with the earliest cases of HIV infection. ${ }^{6}$

The continued resistance to polio immunization campaign in northern Nigeria may be due to failure of the aggregate campaign strategy or its limited success in the region. This is not yet certain. However, studies and reports have linked the variability of the campaign resistance and acceptance in the region to the influences of mass media and interpersonal sources of information on the immunization. ${ }^{1,2,7,8}$

These studies and reports tended to have over-generalized the role communication played in the pattern of acceptance of the campaign in northern Nigeria, thereby leaving incomplete evidence regarding the influence of communication sources on the responses of the local communities to the immunization campaign particularly in high-risk (WPVendemic) areas. This study therefore aims to provide evidence from Zaria local government area on how communication influenced community responses within the following main questions: i) what is the degree of acceptance and resistance of the polio immunization campaign in Zaria local government area; ii) how did mass media and interpersonal communication sources comparatively influenced acceptance of polio immunization campaign in Zaria local government area; iii) which is the most influential of mass media and interpersonal communication sources in the campaign acceptance and resistance decision of individuals in Zaria local government area?
Correspondence: Yakubu Ozohu-Suleiman, Department of Media Studies, Faculty of Arts and Social Sciences, University of Malaya, 50603 Kuala Lumpur, Malaysia.

E-mail: lastbornee@yahoo.co.uk

Key words: polyomelitis, public health, vaccination.

Received for publication: 22 January 2010.

Accepted for publication: 11 March 2010.

This work is licensed under a Creative Commons Attribution 3.0 License (by-nc 3.0).

(C) Copyright Y. Ozohu-Suleiman 2010

Licensee PAGEPress, Italy

Journal of Public Health in Africa 2010; 1:e2

doi:10.4081/jphia.2010.e2

\section{Materials and Methods}

This study adopts survey method, with structured questionnaire as primary data gathering instrument. Survey is appropriate in asking respondents to report on their behaviours, ${ }^{9}$ and enables researcher generate quantitative data with relative ease. ${ }^{10}$

\section{Location of study and population description}

The study is located in Zaria local government area of Kaduna state in Northern Nigeria, being one of the high-risk (WPVendemic) areas in northern Nigeria, where resistance to the polio immunization campaign is high.' ${ }^{1}$ The local government area comprises of thirteen wards, namely: AnguwanFatika; Anguwan-Juma; Dambo; Dutsen-Abba; Gyallesu; Kaura; Kufena; Kwarbai-A; KwarbaiB; Limancin-Kona; Tudun-wada; Tukur-Tukur; Wuciciri.

Like most parts of northern Nigeria, the predominant indigenous population in Zaria local government area is Hausa, who are mainly of the Islamic faith. The 2006 national census figures in Nigeria put the local government area population at 434,745 . For the purpose of this study, populations include adult male and female parents and caregivers in selected locations, regardless of religious and ethnic or tribal denomination.

\section{Sampling, data collection and analysis}

Based on availability of the 2008 immunization monitoring data in Zaria local government area, eight out of thirteen wards in the local government were purposively sampled for the study, using proportional representation method. The wards are Anguwan-Fatika; 
Anguwan-Juma; Kaura; Kwarbai-A; Kwarbai-B; Tudun-Wada; Limancin-Kona; Tukur-Tukur. The total population of the sampled wards is 287,125 people, representing approximately $62 \%$ of the entire population of Zaria local government area. For the purpose of sampling accuracy, 10\% of the population of the eight wards i.e. $10 \%$ of 287,125 were sampled for the study. This gave rise to approximately 28,712 respondents. However, to avoid voluminous and unmanageable data, a sample of ten per cent (10\%) was further drawn from the 28,712 respondents, resulting in approximately 2868 respondents sampled for the study. Again since the population distribution in the eight wards are not the same, to ensure that the sample from each ward is fairly representative of the population of the ward, $10 \%$ of the sample from each ward was taken for administration of questionnaire. The questionnaires were administered casually on respondents who were available at the point of data gathering. Data was collected structurally in the order of listing of the wards, coded and analyzed using descriptive statistical method, aided with computer based Statistical Package for Social Sciences (SPSS).

\section{Results}

Out of 2868 questionnaires distributed among target populations, only 2253 could be retrieved for analysis. This puts the response rate at approximately $78.6 \%$. In relation to the research questions, the principal findings of the study are as follows: $55.1 \%$ of the people of Zaria local government area currently accept polio immunization campaign, while $44.9 \%$ currently resist the polio immunization campaign (Table 1). Interpersonal sources were significantly more influential than the mass media in both campaign acceptance and resistance decisions in the local communities. The influence of interpersonal communication sources is $55.4 \%$ greater than that of mass media in the campaign acceptance mobilization, and also $79.4 \%$ greater than mass media in campaign resistance mobilization in Zaria local government area (Table 2). Friends and Relations are the most influential of interpersonal sources in the campaign acceptance and resistance decision of individuals in the local communities (Table 3). Newspapers and magazines are the major mass media sources through which the resistance to the polio immunization campaign in Zaria local government area was influenced (Table 4).

\section{Discussion}

The preponderance of interpersonal sources of influence in the campaign acceptance and resistance decision of the individuals in the local communities, as shown by the results, is supported in the basic premise of the two-step flow theory that interpersonal contacts produce more influence than mass media in persuasive campaigns. This theory, which forms the basic premise of this study, emphasizes that when mass media and interpersonal communication

Table 1. Campaign acceptance and resistance pattern in Zaria local government area.

\begin{tabular}{lccc}
\hline Wards & Accept campaign & Resist campaign & Total \\
Anguwan-Fatika & $175(7.8 \%)$ & $135(6.0 \%)$ & $310(13.8 \%)$ \\
Anguwan-Juma & $110(4.9 \%)$ & $89(4.0 \%)$ & $199(8.8 \%)$ \\
\hline Kaura & $48(2.1 \%)$ & $31(1.4 \%)$ & $79(3.5 \%)$ \\
Kwarbai-A & $198(8.8 \%)$ & $118(5.2 \%)$ & $316(14.0 \%)$ \\
Kwarbai-B & $188(8.3 \%)$ & $124(5.5 \%)$ & $312(13.8 \%)$ \\
Limancin-kona & $293(13.0 \%)$ & $201(8.9 \%)$ & $494(22.0 \%)$ \\
Tudun-Wada & $88(3.9 \%)$ & $104(4.6 \%)$ & $192(8.5 \%)$ \\
Tukur-Tukur & $141(6.3 \%)$ & $210(9.3 \%)$ & $351(15.6 \%)$ \\
Total & $1241(55.1 \%)$ & $1012(44.9 \%)$ & $2253(100.0 \%)$ \\
\hline
\end{tabular}

Table 2. Campaign acceptance and resistance by source of influence.

\begin{tabular}{|c|c|c|c|c|c|c|}
\hline Wards & $\begin{array}{l}\text { pt campaig } \\
\text { Mass II } \\
\text { media }\end{array}$ & $\begin{array}{l}\text { In: source of } \\
\text { Interpersona } \\
\text { Comm. }\end{array}$ & $\begin{array}{l}\text { f Influence } \\
\text { a Total }\end{array}$ & $\begin{array}{c}\text { Resist camp } \\
\text { Mass } \\
\text { media }\end{array}$ & $\begin{array}{l}\text { iign: source of } \\
\text { Interpersonal } \\
\text { Comm. }\end{array}$ & $\begin{array}{l}\text { f influence } \\
\text { il Total }\end{array}$ \\
\hline Anguwan-Fatika & $34(2.7 \%)$ & $141(11.4 \%)$ & $175(14.1 \%)$ & $12(1.2 \%)$ & $123(12.1 \%)$ & $135(13.3 \%)$ \\
\hline Anguwan-Juma & $30(2.4 \%)$ & $80(6.5 \%)$ & $110(8.9 \%)$ & $8(0.8 \%)$ & $81(8.0 \%)$ & $89(8.8 \%)$ \\
\hline Kaura & $38(3.1 \%)$ & $10(0.8 \%)$ & $48(3.9 \%)$ & $5(0.5 \%)$ & $26(2.6 \%)$ & $31(3.1 \%)$ \\
\hline Kwarbai-A & $20(1.6 \%)$ & $178(14.3 \%)$ & $198(15.9 \%)$ & $10(1.0 \%)$ & $108(10.7 \%)$ & $118(11.7 \%)$ \\
\hline Kwarbai-B & $52(4.2 \%)$ & $136(11.0 \%)$ & $188(15.1 \%)$ & $17(1.7 \%)$ & $107(10.5 \%)$ & $124(12.2 \%)$ \\
\hline Limancin-kona & $32(2.6 \%)$ & 261 (21.0\%) & $293(23.6 \%)$ & $15(1.5 \%)$ & $186(18.4 \%)$ & $201(19.9 \%)$ \\
\hline Tudun-Wada & $36(2.9 \%)$ & $52(4.2 \%)$ & 88 (7.1\%) & $12(1.2 \%)$ & $92(9.1 \%)$ & $104(10.3 \%)$ \\
\hline Tukur-Tukur & $35(2.8 \%)$ & $106(8.5 \%)$ & $141(11.4 \%)$ & $25(2.4 \%)$ & $185(18.3 \%)$ & $210(20.7 \%)$ \\
\hline Total & $277(22.3 \%)$ & $964(77.7 \%)$ & $1241(100.0 \%)$ & $104(10.3 \%)$ & $908(89.7 \%) 1$ & $1012(100.0 \%)$ \\
\hline
\end{tabular}

Table 3. Campaign most influential interpersonal source of information.

\begin{tabular}{|c|c|c|c|c|c|c|c|c|c|c|c|c|}
\hline \multirow[b]{2}{*}{ Wards } & \multicolumn{4}{|c|}{ Accept: most influential interpersonal source } & \multirow[b]{2}{*}{ Others } & \multicolumn{7}{|c|}{ Resist: most influential interpersonal source } \\
\hline & $\begin{array}{l}\text { Trad. } \\
\text { Ruler/ward } \\
\text { head }\end{array}$ & $\begin{array}{c}\text { Husband/ } \\
\text { wife }\end{array}$ & $\begin{array}{l}\text { Friend/ } \\
\text { relation }\end{array}$ & $\begin{array}{l}\text { Religious } \\
\text { leader }\end{array}$ & & $\begin{array}{c}\text { Trad. } \\
\text { ruler/ward } \\
\text { head }\end{array}$ & $\begin{array}{l}\text { Husband/ } \\
\text { wife }\end{array}$ & $\begin{array}{l}\text { Friend/ } \\
\text { relation }\end{array}$ & $\begin{array}{l}\text { Religious } \\
\text { leader }\end{array}$ & Others & Total & $\begin{array}{c}\text { Trad. } \\
\text { ruler/ward } \\
\text { head }\end{array}$ \\
\hline Anguwan-Fatika & 22 (2.3\%) & $41(4.2 \%)$ & $60(6.2 \%)$ & $14(1.5 \%)$ & $4(0.4 \%)$ & $5(0.5 \%)$ & $36(4.2 \%)$ & $63(6.2 \%)$ & $14(1.5 \%)$ & $5(0.4 \%)$ & $123(13.5 \%)$ & $5(0.5 \%)$ \\
\hline Anguwan-Juma & $9(0.9 \%)$ & $24(2.5 \%)$ & $38(3.9 \%)$ & $7(0.7 \%)$ & $2(0.2 \%)$ & $3(0.3 \%)$ & $27(2.5 \%)$ & $45(3.9 \%)$ & $6(0.7 \%)$ & $0(0.2 \%)$ & $81(8.9 \%)$ & $3(0.3 \%)$ \\
\hline Kaura & $1(0.1 \%)$ & $4(0.4 \%)$ & $3(0.3 \%)$ & $2(0.2 \%)$ & $0(0.0 \%)$ & $1(0.1 \%)$ & $4(0.4 \%)$ & $10(0.3 \%)$ & $7(0.2 \%)$ & $4(0.0 \%)$ & $26(2.9 \%)$ & $1(0.1 \%)$ \\
\hline Kwarbai-A & $19(2.0 \%)$ & $51(5.3 \%)$ & $81(8.4 \%)$ & $15(1.6 \%)$ & $12(1.3 \%)$ & $4(0.4 \%)$ & $13(5.3 \%)$ & $68(8.4 \%)$ & $13(1.6 \%)$ & $10(1.3 \%)$ & 108 (11.9\%) & $4(0.4 \%)$ \\
\hline Kwarbai-B & $20(2.1 \%)$ & $42(4.4 \%)$ & $49(5.1 \%)$ & $10(1.0 \%)$ & $15(1.6 \%)$ & $8(0.9 \%)$ & $25(4.4 \%)$ & $53(5.1 \%)$ & $9(1.0 \%)$ & $12(1.6 \%)$ & 107 (11.8\%) & $8(0.9 \%)$ \\
\hline Limancin-kona & $40(4.1 \%) 61$ & $(6.3 \%)$ & $105(10.9 \%)$ & $23(2.4 \%)$ & $32(3.3 \%)$ & $10(1.1 \%)$ & $33(6.3 \%)$ & $110(10.9 \%)$ & $12(2.4 \%)$ & $21(3.3 \%)$ & $186(20.5 \%)$ & $10(1.1 \%)$ \\
\hline Tudun-Wada & $6(0.6 \%)$ & $12(1.3 \%)$ & $19(2.0 \%)$ & $5(0.5 \%)$ & $10(1.0 \%)$ & $4(0.4 \%)$ & $22(1.3 \%)$ & $28(2.0 \%)$ & $11(0.5 \%)$ & $27(1.0 \%)$ & $92(10.1 \%)$ & $4(0.4 \%)$ \\
\hline Tukur-Tukur & $15(1.6 \%)$ & $28(2.9 \%)$ & $42(4.4 \%)$ & $17(1.7 \%)$ & $4(0.4 \%)$ & $6(0.7 \%)$ & $53(2.9 \%)$ & $85(4.4 \%)$ & $26(1.7 \%)$ & $15(0.4 \%)$ & $185(20.4 \%)$ & $6(0.7 \%)$ \\
\hline Total & $132(13.7 \%)$ & $263(27.3 \%)$ & 397 (41.2\%) & $93(9.6 \%)$ & $79(8.2 \%)$ & $41(4.5 \%)$ & $213(23.5 \%)$ & $462(50.9 \%)$ & 98 (10.8\%) & $94(10.3 \%)$ & $908(100.0 \%)$ & 0) $41(4.5 \%)$ \\
\hline
\end{tabular}


Table 4. Campaign most influential media source of information.

\begin{tabular}{lcccccccccc} 
Wards & \multicolumn{3}{c}{ Accept: most influential media sources } & \multicolumn{3}{c}{ Resist: most influential media sources } \\
& Television & Radio & Print & Town Crier & Total & Television & Radio & Print & Town crier & Total \\
Anguwan-Fatika & $10(3.6 \%)$ & $18(6.5 \%)$ & $5(1.8 \%)$ & $1(0.4 \%)$ & $34(12.3 \%)$ & $1(1.0 \%)$ & $4(3.9 \%)$ & $7(6.7 \%)$ & $0(0.0 \%)$ & $12(11.6 \%)$ \\
Anguwan-Juma & $6(2.2 \%)$ & $19(6.9 \%)$ & $5(1.8 \%)$ & $0(0.0 \%)$ & $30(10.8 \%)$ & $0(0.0 \%)$ & $3(2.9 \%)$ & $5(4.8 \%)$ & $0(0.0 \%)$ & $8(7.7 \%)$ \\
\hline Kaura & $31(11.2 \%)$ & $5(1.8 \%)$ & $2(0.7 \%)$ & $0(0.0 \%)$ & $38(13.7 \%)$ & $0(0.0 \%)$ & $3(2.9 \%)$ & $2(1.9 \%)$ & $0(0.0 \%)$ & $5(4.8 \%)$ \\
Kwarbai-A & $4(1.4 \%)$ & $14(5.0 \%)$ & $1(0.4 \%)$ & $1(0.4 \%)$ & $20(7.2 \%)$ & $1(1.0 \%)$ & $3(2.9 \%)$ & $6(5.8 \%)$ & $0(0.0 \%)$ & $10(9.6 \%)$ \\
\hline Kwarbai-B & $12(4.3 \%)$ & $36(13.0 \%)$ & $4(1.4 \%)$ & $0(0.0 \%)$ & $52(18.8 \%)$ & $3(2.9 \%)$ & $5(4.8 \%)$ & $9(8.6 \%)$ & $0(0.0 \%)$ & $17(16.3 \%)$ \\
Limancin-kona & $8(2.9 \%)$ & $21(7.6 \%)$ & $2(0.7 \%)$ & $1(0.4 \%)$ & $32(11.6 \%)$ & $1(1.0 \%)$ & $3(2.9 \%)$ & $11(10.6 \%)$ & $0(0.0 \%)$ & $15(14.4 \%)$ \\
Tudun-Wada & $7(2.5 \%)$ & $24(8.7 \%)$ & $5(1.8 \%)$ & $0(0.0 \%)$ & $36(13.0 \%)$ & $2(1.9 \%)$ & $4(3.9 \%)$ & $6(5.8 \%)$ & $0(0.0 \%)$ & $12(11.6 \%)$ \\
Tukur-Tukur & $17(6.1 \%)$ & $14(5.0 \%)$ & $3(1.1 \%)$ & $1(0.4 \%)$ & $35(12.6 \%)$ & $5(4.8 \%)$ & $7(6.7 \%)$ & $13(12.5 \%)$ & $0(0.0 \%)$ & $25(24.0 \%)$ \\
\hline Total & $95(34.2 \%)$ & $151(54.5 \%)$ & $27(9.7 \%)$ & $4(1.6 \%)$ & $277(100.0 \%)$ & $13(12.5 \%)$ & $32(30.8 \%)$ & $59(56.7 \%)$ & $0(0.0 \%)$ & $104(100.0 \%)$ \\
\hline
\end{tabular}

sources are compared or are in conflict, interpersonal sources wields greater influence. ${ }^{11}$ Such influence displayed by interpersonal sources over mass media in this study may be connected in relative degrees to the risks perceived to be associated with the mass media sources, particularly because in Nigeria mass media tends to be perceived to be sympathetic with the government. However, this cannot be certain until a risk perception analysis of the campaign resistance is carried out.

Again, this finding is relevant in clarifying the debate on declaration of universal superiority of interpersonal communication over mass media in persuasive campaign, which was left unchallenged until a research on Measles immunization campaign conducted in the Philippine proved that the influence of interpersonal communication in persuasive campaign is relative to the community where it is used and the quality of development of the media in such community. ${ }^{12}$

It is equally not surprising that newspapers and magazines are found in this study as most influential media sources in the resistance to the polio immunization campaign in Zaria. Most of the indigenous television networks are not accessible by the local communities in Zaria, being a predominantly rural location. However, the Nigeria television authority (NTA) recently established a transmission station in Zaria. This has provided access to government's most advocative television network in Zaria. As can be seen in the results of this study, the influence of television on the polio campaign acceptance was minimal. This is probably because the most accessible network (NTA) is commonly known to be pro-government, and therefore most probably unable to secure significant trust in the communities.

This also calls for a reflection on the question of trust in information sources in the polio campaign. As shown by this study results, friends and relationships are the most influential source of interpersonal communication in both campaign acceptance and resistance decisions of individuals in the local communities. This is a significant departure from the widespread belief that traditional rulers were the greatest source of interpersonal influence in community acceptance of the campaign, and perhaps more importantly a support to Obadare's argument that people in northern Nigeria genuinely resist the polio campaign due to a lack of trust in the government ${ }^{4}$ or better still, political leadership.

Concerning the levels of acceptance and resistance to the polio immunization campaign in Zaria, the findings of this study show a very narrow difference. Only $55.1 \%$ of the populations currently accept the campaign, while $44.9 \%$ resist the campaign. The narrow gap of $10.2 \%$ between the levels of campaign acceptance and resistance is indicative of the difficulties still faced in the polio eradication in northern Nigeria.

\section{Conclusions}

It must be pointed out that data gathering process in this study was inhibited by some cultural beliefs that limited researcher's access to women. This affected the gender representativeness of the data. Against this backdrop, and based on the findings of this study, the researcher concludes that a polio eradication campaign, backed with competent and sufficient communication expertise utilizing knowledge-based indigenous interpersonal communication strategies will likely result in greater community acceptance in northern Nigeria. The applicability of this conclusion may however depend largely on the following recommendations:

Further Research: a risk perception study should be undertaken to analyze the dimensions and degree of risks associated with the resistance to the polio immunization campaign in northern Nigeria.

Health Campaigns 1: polio immunization and similar health interventions campaigns should factor in commonly held attitudes, norms and practices of the people pertaining to health. Indeed, understanding the cultural backgrounds, religious beliefs, group identities and life experiences of communities and their individuals who shape the reception of messages will enhance a knowledge-based communication intervention in public health campaigns.

Health Campaigns 2: the campaign should explore more of interpersonal communication strategies in reaching target populations, since it has been proven to be more efficient in persuasive campaigns of this nature.

Ethics: affected communities should be encouraged to participate directly in determining their health priorities and designing health communication campaigns in their communities.

\section{References}

1. World Health Organization, Kaduna State, 2008. Reasons for rejection of vaccinations in Kaduna State. www.who.int

2. Renne E. Perspectives on polio and immunization in Northern Nigeria. Soc Sci Med 2006;63:1857-69.

3. Muhammed M.B. Factors responsible for rejection of polio immunization campaign: a case study of Tarauni local government area in Kano state. 2003, a master of Public Health thesis, Department of Community Medicine, Ahmadu Bello University, Zaria, Nigeria.

4. Obadare E. A crisis of trust: history, politics, religion and the polio controversy in Northern Nigeria. Patterns of Prejudice 2005;39:265-84.

5. Olusanya B. Polio-vaccination boycott in Nigeria. Lancet 2004;363:1912.

6. BBC News. Nigeria Muslims Oppose Polio Vaccination. 27 June 2002, 19:29 GMT http://news.bbc.co.uk/2/low/africa/2070634. stm

7. Njoku G. Fight against polio in Nigeria focuses on community involvement. http://www.unicef.org/ infobycountry/nigeria_38450.html. 
8. Jaulmes C. Polio immunization drive reaches children in Koranic schools of northern Nigeria. http://www.unicef.org/ infobycountry/nigeria_39432.html. 2007. Retrieved November 52009.

9. Anderson JA, Meyer TP. Mediated communication: a social action perspective. 1988 ,
SAGE Publications, CA, USA.

10. Tejumaiye A. Mass communication research: an introduction. 1st ed. 2003. Ibadan Sceptre University Press, Nigeria.

11. Robinson JP. Interpersonal influence in election campaign: two-step flow. Public Opin Q 1976;40:304-19.
12. Cabanero-Verzosa C. Strategic communication for development projects: a toolkit for task team leaders. 2005, The World Bank, Washington, DC, USA. 